\title{
COMPUTER-AIDED WORKFLOW DESIGNING FOR QOS CONTROL BASED ON ONTOLOGY
}

\author{
${ }^{1}$ Larysa S. Globa, ${ }^{1}$ Maryna A. Popova, ${ }^{1}$ Nataliia A. Yushko, ${ }^{2}$ Lela Mirtskhulava \\ ${ }^{1}$ Institute of Telecomunication Systems \\ Igor Sikorsky Kyiv Politechnic Institute, Kyiv, Ukraine \\ ${ }^{2}$ Department of Computer Science \\ Iv. Javakishvili Tbilisi State University/San Diego State University Georgia, Tbilisi, Georgia
}

Background. The rapid development of technologies in various fields of business, including in telecommunications requires an increasing level of service provision, because the formation of a market for network communication services has increased attention to issues of quality control, both by regulators and by the providers themselves. In order to meet a given level of quality of service, telecommunication operators develop algorithms and solutions for providing quality control services based on various criteria. However, these solutions are not universal for different types of indicators (quantitative, qualitative, etc.) of quality of service.

Objective. The paper presents the approach to automating workflows and their components (functional services, connections and rules of interaction) by designing processes based on computer-aided generation of both a set of services that are components of workflows and the sequence of their execution using ontologies. Ontology serves as meta-model of the workflow, services, subject domain and logical rules that establish relationships between functional services.

Methods. The implementation of the proposed approach was realized using an ontological modeling, workflow modeling standards and methods of computer-aided designing.

Results. An ontological model of service quality indicators was developed, as well as dynamically changing workflow that guarantees the quality of service control universality was designed. For computer-aided workflows generation the software environment has been developed, the performance of which is tested on the example of workflow designing tool IT TODOS for developing and modifying ontologies and generating workflow scheme using BPMN.

Conclusions. The proposed approach makes the process of quality of service control more transparent and reduces the involvement of analysts in this process. Such an approach is flexible and universal for usage in any subject domain by uploading relevant data to the registers. It also provides the process of the quality of service control automation and the solution encapsulation enabling employees to use the solution provided at any level without the expert analyst involvement.

Keywords: workflow; ontology; orchestrator; computer-aided design; microservices; Quality of Service; telecommunication.

\section{INTRODUCTION}

Currently the Internet has quite firmly entered in the life of modern human. Thanks to the introduction of new technologies and lower access costs there has been a steady increase in the number of users. According to a Factum Group study commissioned by the Committee of the Internet Association of Ukraine at the end of the third quarter of 2019 in Ukraine there were about $71 \%$ of the total population of the country (22, 96 million people) were Internet users. One of the reasons for this growth is the population "SmartPhoneization". Today, $22 \%$ of users access the Internet exclusively using smartphones. Although for a significant part of new users in 2019 the smartphone was the first and only device to access the network, $65 \%$ of users are still home subscribers [1]. At the same time, the number of companies providing Internet access is much smaller - a little over a thousand throughout Ukraine (according to the 2ip.ua Internet service -1052 ).

Providers are actively working to maintain and strengthen their position. The market for provider services is actively developing not only in big cities but also in the provinces where large providers are actively working. Operation and income of companies providing Internet access depend on the quality of service.
Intensive development of information and communication technologies, applications requiring high data transfer speeds, traffic growth and the associated tendency to increase the likelihood of overloading the communication network, leads to degradation of the quality of communication services.

In the 21 st century, providers have faced challenges requiring new organizational models and technologies for inter-organizational collaboration, integration, and communication. The traditional processes based on tasks separation are replaced by dynamic development and implementation networks with flat organizational structures. Internet service providers participate in several business processes at the same time, and the role of a particular provider is different in each business process. This requires strong compatibility (interoperability) between various local, organization-specific workflow management systems (Workflow Management Systems, WfMS). The highly dynamic nature of the provider market and the necessary mechanisms for coordination and processing of data concerning quality of service control make demands for flexibility in the formation and implementation of the workflow even more firm.

A prerequisite for this is a unified standard for the entire supply chain of services in fact for the entire provider 
industry. Such standard may include regulations, licenses, client contracts, etc. It is proposed to use ontologies as formalized model of the standard for the telecommunication service provisions and this approach should be universal for all providers.

Agent-based workflow management requires a machinereadable representation of subject domain and workflow description knowledge. The research presents a domain ontology which includes the description of the services provided, web-services, queries to inter-organizational systems for performing workflows, the workflow model meta-description, etc., and guaranteeing compatibility on a semantic level.

System integration and the information presentation is becoming increasingly important. The main obstacle to integration is semantic differences [2] which can be eliminated by standardizing the business process, but this possibility is debatable as customers require an individual approach to service. Standardization is certainly possible at the component level but not for the entire business process. Business Process Modeling is a set of activities associated with the presentation creation for an existing or proposed business process. In process modeling, information is used by an expert analyst who generates a flow of actions from the beginning until the goal is reached.

In order to facilitate integration Web Services are being used [3]. These are web-based services carrying out a small part of a business process in order to making reliable integration. During considering the up-to-day Web Services the focus is on transferring the content of the information.

The aim of the research is to create a software solution for quality of telecommunication services control based on the ontology of quality benchmarks declared in the regulatory documentation of providers, ensuring interoperability of data from different companies and dynamically changing workflow to provide universality and computer-aided quality of service control.

The main task of the paper is to modify the centralized form of service interaction ("orchestration") so as to exclude low-level details of the interaction with scenarios description, while maintaining the rules of service interaction in the ontology. That is, in terms of a specific request or requirement for a particular computing script, execute it by composing and orchestrating services and constructing their workflows in an automated manner based on the general requirements of the users.

Unlike similar existing systems, users do not need to have knowledge of the details of the interaction with the services and the availability of specific services, and therefore can create abstract computing scenarios without special training.

This paper is organized as follows. After the Introduction, section 2 contains state of the art that approaches a solution to review this problem in different sources in current state. Section 3 is devoted to the formalized description of model of quality of telecommunication service standards. Section 4 provides an example of software implementations and further research perspectives. Section 5 includes the summary and outlook on future work.

\section{STATE OF THE ART AND BACKGROUND}

The ability to create services tailored to specific customers rapidly and efficiently is a clear business benefit to clusters of Internet Service Providers (ISPs); indeed, it is a necessary requirement for the survival of such a cluster. Offering mere Internet connectivity is insufficient in today's competitive environment, which is especially important for the local providers in small towns, and the composition of value-added services based on workflow technologies give such ISPs considerable business advantages [4]. This is what [5] call Internet-scale workflow.

To date the work of telecommunication providers, services are regulated by documents which are an array of unstructured or poorly structured text information. The results of the quality of service analysis and various studies of the market providers are described by quantitative indicators for the presentation of which tables are most often used. Thus, the integration of data from different providers requires the provision of interactive, interoperable and semantic connectivity of information resources, regardless of their format, standards, and creation technology.

Although many companies have linked their information systems for business processes, the interfaces are nonstandardized and require custom programming. Also, you should keep in mind that the concept of interoperability among workflow systems can be extended to include interactions among other types of systems and services.

According to [5] in the near future, process interfaces (such as the structure of context and result data) will be established between individual companies. However, there are many emerging initiatives that attempt to standardize schema for information exchanged in interenterprise business interactions, interfaces of services used in these interactions, or even cross-enterprise business processes. The Workflow Management Coalition (WfMC) expects to synchronize the Wf-XML specification with such standards as they evolve. Although Wf-XML does not define a standard for business process interfaces, it provides a language and protocol that enables interaction among such processes.

The analysis of the most significant business process management and workflow technologies that are currently available based on the market and technical aspects of each technology and available support for the technology in tools and other products are described in [4]. The result of the analysis has led to the following technologies being recommended for using in this research:

- $\quad$ BPMN for business process modelling;

- BPMN and potentially UML activities for choreography;

- BPEL4WS for orchestration;

- $\mathrm{XML}$ for workflow management.

\section{FORMALIZED MODEL DESCRIPTION OF THE TELECOMMUNICATION SERVICES STANDARD}

An ontological data model is proposed as a domain data model that can be represented as a tree structure.

In general terms an ontology means the system of some subject area concepts that are represented as a set of entities connected by different relationships. Ontologies are used for 
the formal specifications of concepts and relationships that characterize a particular area of knowledge. The advantage of ontologies as a way of presenting knowledge is their formal structure which simplifies their computer processing $[6,7]$.

In a general case, the ontology of some subject area is formally represented by an ordered three:

$$
O=\{X(w, s, q), R(w, s, q), F\}
$$

where $X, R, F$ - the finite sets appropriately: $X$ - the set of registries $\left(X_{w}\right.$ - register of workflows, $X_{s}$ - register of services, $X_{q}$-register of queries), $R$ - the set of relationship between registries, $F$ - the set of the interpretation functions $X$ and/or $R$.

An ontological structure allows the process of heterogeneous, unstructured data using algorithms to construct a thematic representation of text content as a hierarchical structure that simulates the construction of related text. Since the basis of the system is a certain semantic basis of the subject area which allows organizing "meaningful" analysis of information in electronic documents, as well as to identify potential relationships between objects, in the script that processes unstructured data using ontology is greatly simplified [8]. [9]:

In order to create an ontological structure, it is necessary

- To carry out preliminary analysis of a subject area. At this stage, it is needed to systematize knowledge, to document certain terms and concepts within the domain, and to define a certain supporting structure.

- The next step is to build a graph of the domain.

- The final step is to design a graphic (visual) of the domain ontology and to formalize the description of the final creation.

For example, four major registries (bases) have been identified to build a quality of telecommunication service control platforms:

- Register of Services;

- Register of Microservices;

- Register of Workflows;

- Register of Queries.

Register of Services is an ontological structure that contains a list of all services provided by a telecommunications provider.

The register lists the main services of the provider: they are divided into classes (Internet, TV, OTT), the levels of service (top lever offers, second level offerings), the service characteristics, types of users, valid values, etc. are specified. All service data can be viewed in a structured manner using an object ontology.

Register of Microservices is an ontological structure that will be used to control complex technical parameters, which in turn are part of an overall assessment quality of service. This register contains a description of all microservice parameters (input data, output data, input / output data type, value range, etc.) and includes links to the microservice itself or its code.

Register of Workflows is an ontological structure containing a set of computational scripts to execute a workflow with the described parameters. All executed scenarios are based on microservices. That is, in other words, microservices are represented as structured blocks that are arranged and executed in a certain sequence. BPMN 2.0 notation is used to describe and depict workflows.

Register of Queries is an ontological structure which is in a form of the queries descriptions and their corresponding workflow. Each query is associated with a corresponding one-to-one key process.

\section{AN EXAMPLE OF SOFTWARE IMPLEMENTATION}

There are numerous business workflow design technologies available in this dynamic and are constantly evolving the area and tasks which are to select the right combination of notations, languages, mappings and tools appropriate to insure the ISP interoperability.

IT-TODOS was chosen to do the task of ensuring interactive interoperable semantic connectivity of the networks ontological presentations information arrays which describe the telecommunication services quality indicators based on the semantic-linguistic analysis of their contents. [10].

The IT-TODOS toolkit is intended for the formation of domain ontologies and provides interoperability of information not only at the structural and syntactic levels but also at the semantic-linguistic level. At the same time, the user is not required to know algorithmic languages this significantly reduces the cost of programming and expert services. The telecommunications quality of service control ontology is the XML file that describes various parameters and their properties that are used to fulfill service quality control queries.

It consists of 31 nodes combined in 3 classes based on the "IS-ARE" belonging property (Fig. 1). 


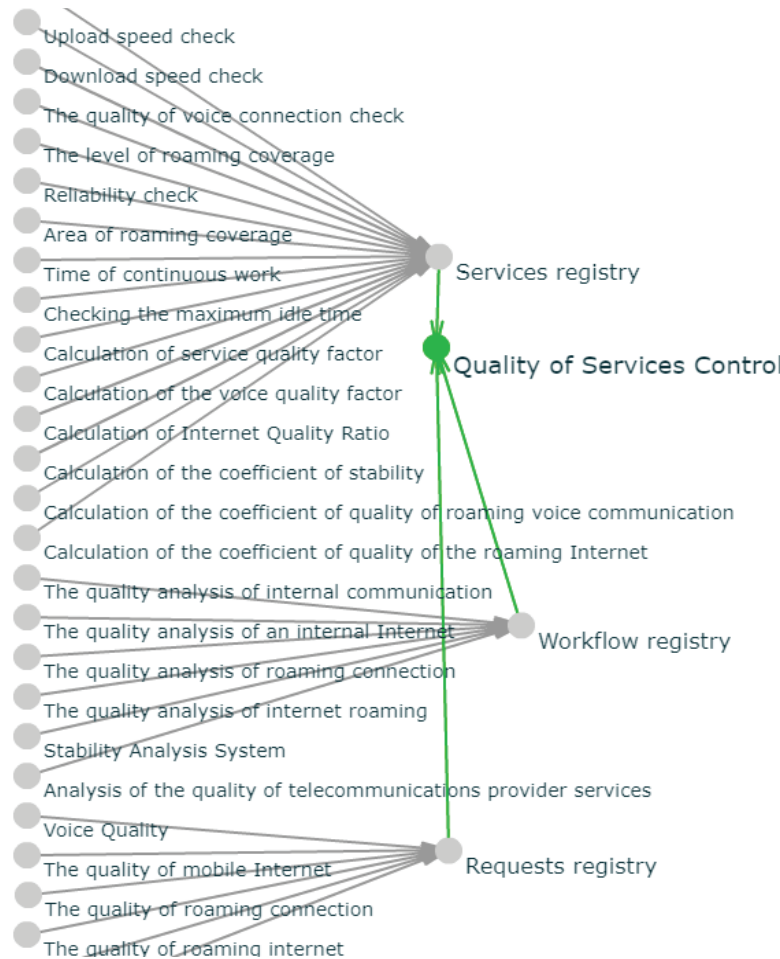

Fig. 1. Ontology of quality of service control in the form of a network graph

Workflow that chosen as an example "The quality analysis of roaming connection" is described by metadata, the values of which are calculated based on the computeraided workflow (Fig. 2).

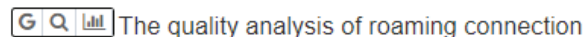

- Input data
Number of voice sequences 1400
Offering Prepaid 150
Prepaid 200
Planned hours of operation 20
Reality resource 0.95
Region Ukraine
Tecnology Optic
Transmission direction Direct
Output data
Roaming quality factor 1
Stability factor The calculation of the roaming quality analysis is performed based on
the calculation of coverage coefficients (roaming), continuous operation, reliability, etc.
Description The calculation of the roaming quality analysis is performed based on the
calculation of coverage coefficients (roaming), continuous operation, reliability, etc.
The quality analysis of roaming connection BPMN

Fig. 2. Metadata describing a specific workflow

The attribute filter eliminates objects whose metadata attributes (metadata) do not correspond to the specified parameters (Fig. 3).

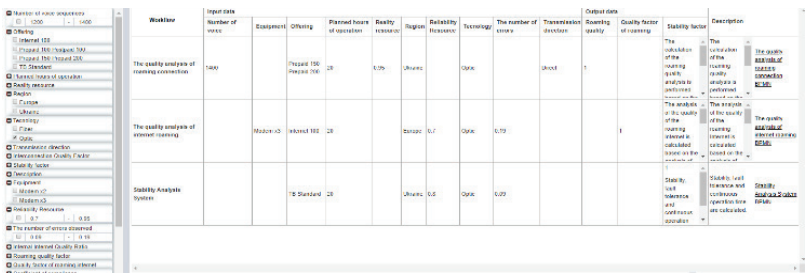

Fig. 3. Metadata values describing benchmarks for the quality of services

Using the XML parsing / generating modules, the original file was converted to JSON format. Further processing of the ontology file allowed generating a model which describes the workflow in BPMN format.

The BPMN - is the module that visualizes the workflow, data flow and variables in the web user interface (Fig. 4), which allows the user to edit the input at each stage of the process.

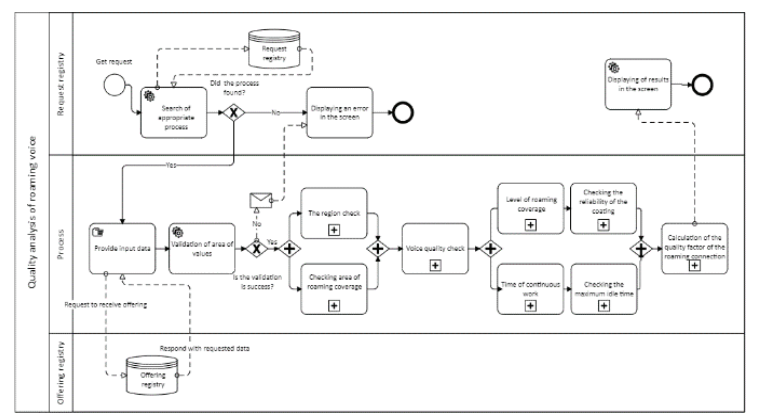

Fig. 4. BPMN Workflow Model

Software implementation of the computer-aided workflow formation algorithm involves the plan formation for its execution, that is, the sequence of its services execution by means of WSBPEL. WSBPEL is open XMLbased language for the formal specification of business processes and business interaction protocols. It defines an interoperable integration model that should challenge the expansion of computer-aided process integration in both intra-corporate and business-to-business spaces. The general logic of the process can be implemented with a programming-in-the-large approach that enables business analysts to express their ideas in the most formal way, easily without being involved in technical solutions.

\section{THE SUMMARY AND OUTLOOK ON FUTURE WORK}

The paper deals with an approach to development of the ontological structure for computer-aided workflows and their components (functional services, relationships, and rules of interaction) designed based on generating both a set of services that are components of the workflows and the sequence of their execution using the workflow metamodels, services, subject domain, logical rules that establish relationships between the functional services. The formalized description of ontological domain models, functional services and workflows, as well as operations for computeraided workflow formation using links and rules established before ontological models are offered.

The proposed approach is flexible and universal for usage in any subject domain by uploading relevant data to the registers. It also provides the process of the quality service control automation and the solution encapsulation enabling 
employees to use the solution provided at any level without the expert analyst involvement. This approach simplifies workflow modification by replacing the corresponding workflow in the created ontological structure. Using the subject domain ontology as a register of meta-descriptions of functional services will allow designing computer-aided workflows and to define a functional service from a set of similar services that most closely match the usage conditions that are determined by the input data flow.

Further researches will be devoted to more detailed consideration of computer-aided workflow design processes from sets of functional services, in particular, the program code of computer-aided generation for the workflows' execution.

\section{REFERENCES}

[1] Internet penetration in Ukraine [Electronic resources]. - 2019. - Type of resource access: https://inau.ua/sites/default/files/file/1910/dani_ustanovchyh_doslidzh en_iii_kvartal_2019_roku.pdf.

[2] S. M. Embury, S. M. Brandt, J. S.Robinson, I. Sutherland, F. A. Bisby, W. A. Gray, A. C. Jones, and R. J. White, in Information Systems, 26(8), pp. 657-689, 2001.

[3] M. Skulysh, O. Romanov, L. Globa, I. Husyeva, "Managing the Process of Servicing Hybrid Telecommunications Services. Quality Control and Interaction Procedure of Service Subsystems", in
Advances in Soft and Hard Computing, 2019, doi: 10.1007/978-3030-03314-9_22.

[4] K.-P. Eckert, Y. Glickman, J. Hall, R. Knapik, R. Renk, T.-F. Fortiș, A. Cicortas, "Workflow technologies for a virtual ISP" in Exploiting the knowledge economy. Vol.2 : Issues, applications and case studies, pp. 1631-1638, 2006.

[5] J. G. Hayes, E. Peyrovian, S. Sarin, M.-T. Schmidt, K. D. Swenson, R. Weber, "Workflow interoperability standards for the Internet" in Internet Computing, IEEE. 4., pp. 37-45, 2000, doi: $10.1109 / 4236.845389$

[6] G. Budin, "Ontology-driven translation management", Knowledge Systems and Translation, 2005, doi: 10.1515/9783110924305.103.

[7] D. Oberle, "How ontologies benefit enterprise applications", in Semantic Web, 5 (6), 2014, pp. 473-491, doi:10.3233/SW-130114.

[8] S. I. Antonov, S. G. Redko, “Automation of Unstructured Data Management within the Enterprise Content Management System", in Scientific and technical statements of SPbSPU, №5, pp. 277-282, 2009.

[9] M. A. Popova, "A model of the ontological interface of aggregation of information resources and means of GIS", in International Journal "Information Technologies and Knowledge", Vol. 7, Number 4, pp. 362-370, 2013

[10] V. Velichko, M. Popova, V. Prychodniuk, and O. Stryzhak, "TODOS - IT-platform for the formation of transdisciplinary informational environments," Armament Mil. Equip. Syst., vol. 1, no. 49, pp. 10$19,2017$.

Глоба Л.С., Попова М.А., Юико Н.А., Миртшулава Л.

Проектування робочого процесу для контролю QOS на основі онтології

Проблематика. Стрімкий розвиток технологій у різних сферах бізнесу, в тому числі в телекомунікаціях, вимагає підвищення рівня надання послуг, оскільки формування ринку послуг мережевого зв'язку підвищило увагу до питань контролю якості, як з боку регуляторів, так і з боку самих провайдерів. Для надання заданого рівня якості обслуговування оператори зв'язку розробляють алгоритми та рішення щодо надання послуг з контролю якості на основі різних критеріїв. Однак, такі рішення не є універсальними для різних типів показників якості обслуговування (кількісних, якісних, тощо).

Мета дослідження. У статті представлений підхід до автоматизації робочих процесів та їх компонентів (функціональні сервіси, відношення та правила взаємодії) шляхом проектування процесів на основі комп'ютерної генерації як набору служб, що є компонентами робочих процесів, так і послідовності їх виконання за допомогою онтологій. Онтологія виступає у якості мета-моделі робочого процесу, сервісів, предметної області та логічних правил, які встановлюють зв'язки між функціональними службами.

Методика реалізації. Запропонований підхід реалізовується 3 використанням онтологічного моделювання, стандартів моделювання робочих процесів та методів автоматизованого проектування.

Результати дослідження. В результаті дослідження розроблено онтологічну модель показників якості послуг, а також динамічно-змінюваний робочий процес, що гарантує універсальність якості контролю послуг. Для автоматизованого генерування робочих процесів розроблено програмне середовище, продуктивність якого тестується на прикладі інструменту проектування робочого процесу - IT TODOS для розробки та модифікації онтологій та генерації схеми робочого процесу за допомогою BPMN.

Висновки. Запропонований підхід робить процес контролю якості послуг більш прозорим і зменшує залучення аналітиків до цього процесу. Такий підхід є гнучким та універсальним для використання в будь-якій предметній області шляхом завантаження відповідних даних до регістрів. Він також забезпечує автоматизацію процесу управління якістю сервісів та інкапсуляцію рішень, що дозволяє працівникам використовувати рішення, які надаються на будь-якому рівні, без участі експертного аналітика.

Ключові слова: робочий процес; онтологія; оркестратор; комп'ютерний дизайн; мікросервіси; якість обслуговування; телекомунікації. 
Глоба Л.С., Попова М.А., Юшко Н.А., Миртшулава Л.

Проектирование рабочего процесса для контроля QOS на основе онтологии

Проблематика. Стремительное развитие технологий в различных сферах бизнеса, в том числе в телекоммуникациях, требует повышения уровня предоставления услуг, поскольку формирование рынка услуг сетевой связи повысило внимание к вопросам контроля качества, как со стороны регуляторов, так и со стороны самих провайдеров. Для предоставления заданного уровня качества обслуживания операторы связи разрабатывают алгоритмы и решения о предоставлении услуг по контролю качества на основе различных критериев. Однако, такие решения не являются универсальными для различных типов показателей качества обслуживания (количественных, качественных и т.д.).

Цель исследования. В статье представлен подход к автоматизации рабочих процессов и их компонентов (функциональные сервисы, отношение и правила взаимодействия) путем проектирования процессов на основе компьютерной генерации как набора служб, являющихся компонентами рабочих процессов, так и последовательности их выполнения с помощью онтологий. Онтология выступает в качестве метамодели рабочего процесса, сервисов, предметной области и логических правил, устанавливающих связи между функциональными службами.

Методика реализации. Предложенный подход реализуется с использованием онтологического моделирования, стандартов моделирования рабочих процессов и методов автоматизированного проектирования.

Результаты исследования. В результате исследования разработано онтологическую модель показателей качества услуг, а также динамически меняющийся рабочий процесс, который гарантирует универсальность качества контроля над услугами. Для автоматизированного генерирования рабочих процессов разработано программную среду, производительность которой тестируется на примере инструмента проектирования рабочего процесса - IT TODOS для разработки и модификации онтологий и генерации схемы рабочего процесса с помощью BPMN.

Выводы. Предложенный подход делает процесс контроля качества услуг более прозрачным и уменьшает привлечения аналитиков к этому процессу. Такой подход является гибким и универсальным для использования в любой предметной области путем загрузки соответствующих данных в регистры. Он также обеспечивает автоматизацию процесса управления качеством сервисов и инкапсуляцию решений, позволяя работникам использовать решения, которые предоставляются на любом уровне, без участия экспертного аналитика.

Ключевые слова: рабочий процесс; онтология; оркестратор; компьютерный дизайн; микросервисы; качество обслуживания; телекоммуникации. 